\title{
Thermal and evaporative resistance measured in a vertically and a horizontally oriented air gap by Permetest skin model
}

DOI: $10.35530 / I T .072 .02 .202038$

\section{ABSTRACT - REZUMAT \\ Thermal and evaporative resistance measured in a vertically and a horizontally oriented air gap by Permetest skin model}

This paper is a study of the correlation of the thermal resistance $\left(R_{c t}\right)$ and the evaporative resistance $\left(R_{\text {et }}\right)$ in vertically and horizontally oriented air gaps by using the portable Permetest skin model. Experiments were done in a climatic chamber; an isothermal condition for $R_{\text {et }}$ tests and non-isothermal condition for $R_{c t}$ tests. Foamed polyethylene air gap distance rings were prepared with a thickness of 2, 4 and $5 \mathrm{~mm}$ and their combinations to simulate the air gap distance from 0 to $16 \mathrm{~mm}$ which is more than the expected average gap in clothing systems. Test samples were woven fabric of 100 percent cotton, 100 percent polyester and their blends plus 100 percent of polypropylene, all have similar weight and structure. Results showed that with the increasing thickness of the air gap, $R_{c t}$ increased in a polynomial trend and $R_{e t}$ in a linear proportional rate up to $12 \mathrm{~mm}$ then started to change due to the effect of free convection and the different properties of materials. The surprising positive observation is that results from the horizontally and vertically oriented air gaps are very similar, and most of the results from the vertical air gap are slightly lower than the results from the horizontal air gap in all materials.

Keywords: evaporative resistance, thermal resistance, Permetest skin model, vertical orientation, horizontal orientation, woven materials

Rezistența termică și rezistenţa la vapori de apă măsurate în straturi de aer orientate vertical și orizontal utilizând modelul de piele Permetest

Această lucrare este un studiu al corelației rezistenței termice $\left(R_{c t}\right)$ și rezistenței rezistenţei la vapori de apă $\left(R_{\text {et }}\right)$ în straturi de aer orientate vertical și orizontal, utilizând modelul portabil de piele Permetest. Experimentele au fost realizate într-o cameră climatică; în condiții izoterme pentru testele $R_{\text {et }}$ și în condiții neizoterme pentru testele $R_{c t}$. Au fost pregătite inelele de distanță a stratului de aer din spuma de polietilenă cu o grosime de 2, 4 și 5 mm și combinațiile lor, pentru a simula grosimea stratului de aer de la 0 la $16 \mathrm{~mm}$, care reprezintă mai mult decât grosimea medie în sistemele de îmbrăcăminte. Probele de testare au fost țesături din 100\% bumbac, din 100\% poliester și amestecurile lor plus din $100 \%$ polipropilenă, cu masă și structură similare. Rezultatele au arătat că, odată cu creșterea grosimii stratului de aer, $R_{c t}$ a crescut într-o tendință polinomială, iar $R_{\text {et }}$ într-o rată proporțională liniară de până la 12 mm, apoi a început să se modifice datorită influenței convecției libere și a diferitelor proprietăți ale materialelor textile. Observația pozitivă surprinzătoare este că rezultatele straturilor de aer orientate orizontal și vertical sunt foarte similare, iar rezultatele obţinute în stratul de aer vertical sunt ușor mai scăzute decât cele obținute în stratul de aer orizontal pentru toate materialele textile.

Cuvinte-cheie: rezistență la vapori de apă, rezistență termică, model de piele Permetest, orientare verticală, orientare orizontală, țesături

\section{INTRODUCTION}

The air gap in clothing patternmaking is the wearing ease for ergonomic movement. It is everywhere around the wearer's body when he put on clothes to give him the freedom of movement and the thermal protection from the cold. Depending on the posture and ergonomic movement, the orientation of the air gap can be vertical, horizontal or at an angle.

Researches on the air gap related to clothing comfort in articles are either using thermal manikin (vertical air gap) or sweating guarded hot plate (horizontal air gap) so called skin model for tests; for examples, using skin model and thermal manikin for determination of thermophysiological properties of different garments and materials like protective clothing, multi-layered garments, fabrics in the dry and wet state, footwear materials and for testing of clothing and fabric parameters [1-6] by using both apparatuses separately but not the comparison between them. Articles on vertical air gap related to clothing comfort are just a few; like Satusumoto et al. [7] compared quasi-clothing heat transfer between a vertical hot plate and the thermal manikin and concluded that "the vertical hot plate was more accurate than the thermal manikin because of the manikin could not reproduce the same setup of construction factors like precise air 
space sizes". The research is interesting to use the vertical hot plate skin model for the test but only the schematic is shown in the article which is not clarified enough to understand how this apparatus operates in the experiment, and there is no mention of any recognized procedure standard is applied to the vertical skin model test. More, using space bars to keep the air gap distance even is not realistic since in real life clothing hanging on the body will be naturally influenced by the gravity, mechanical properties of the fabric, posture of the body, environmental conditions and other factors, which will influence the evenness of the air gap. Udayraj et al. [8] concluded that vertical air gap orientation has a higher protective value than horizontally oriented air gap in firefighter protective clothing. To understand more about the difference between the orientations of the air gap, an experiment was set up based on seven samples of woven materials, five air gap distances, vertical $(\mathrm{V}) /$ horizontal $(\mathrm{H})$ orientation and $R_{c t} / R_{e t}$ two types of test. However, when using a standard skin model in the vertical or horizontal orientation, serious problems arise because the testing surface area is usually large and the test involving the air gap is practically impossible. The textile material will drape (deform) around the centre area, the effective air gap gets reduced and the measurement suffers from a big error. Moreover, standard skin models as their large size in the vertical direction will cause an uneven distribution of water within the porous measuring plate of the device. Foreseeing these issues of standard skin models, a non-destructive Permetest skin model is chosen [9] which has a small diameter $(8 \mathrm{~cm})$ testing plate and a slightly curved surface to allow a very secure and close contact with materials even with air gap distance up to $16 \mathrm{~mm}$ and still keeps the material flat for testing. The portable size of Permetest also gives it the advantage of turning a horizontally oriented test into a vertically oriented test in a second. In real life, most of the clothing systems' air gaps are vertically oriented, for example; sleeves, trousers, torso and so on that understanding the relationship of horizontal and vertical air gaps is crucial. More, the Permetest skin model enables the measurement of thermophysiological parameters of fabric systems consisting of multi-layered fabrics with air gaps between these fabrics. This solution can serve for experimental determination of thermal and evaporative resistance of real garment systems which involve gaps extending from 2 to 16 millimetres.

\section{EXPERIMENT}

\section{Materials and methods}

Seven samples of material were 100 percent cotton, 100 percent polyester and their blends plus 100 percent polypropylene as the counter sample. All samples were purchased from the same textile manufactory except $20 \%$ and $65 \%$ polyester/cotton blends were from one local retail store. Tested samples were woven material and had a similar square mass; their structures and their properties were tested by Fx3300; Moisture Management Tester; Planimeter to obtain the mean values which are shown in table 1. Air gap distance rings were used to create the preferred air gap sizes for the experiment and were made of 100 percent foamed polyethylene (with very low thermal conductivity reaching $0,035 \mathrm{~W} / \mathrm{m} / \mathrm{K}$ ), relatively good conditions for the possible development of free convection between the sample and the simulated human skin (perforated hotplate) are maintained. The distant rings were prepared with a thickness of 2, 4 and $5 \mathrm{~mm}$ and their combinations to simulate the air gaps from 2 to $16 \mathrm{~mm}$, which is more than for the expected average gap in clothing systems [10, 11]; details and usage are presented in table 2. To balance the thickness of the air gap distance created by the stack of rings and to maintain the smooth air current flew inside the wind channel, two types of air gap distance ring were cut: outer rings were put around the base of the hotplate for

\begin{tabular}{|c|c|c|c|c|c|c|c|}
\hline \multicolumn{8}{|c|}{ SEVEN TESTED MATERIALS AND THEIR PROPERTIES } \\
\hline Tested materials & $\begin{array}{c}100 \% \\
\text { Cotton }\end{array}$ & $\begin{array}{c}80 / 20 \% \\
\text { Cotton/ } \\
\text { Polyester }\end{array}$ & $\begin{array}{c}70 / 30 \% \\
\text { Cotton/ } \\
\text { Polyester }\end{array}$ & $\begin{array}{c}50 / 50 \% \\
\text { Cotton/ } \\
\text { Polyester }\end{array}$ & $\begin{array}{c}35 / 65 \% \\
\text { Cotton/ } \\
\text { Polyester }\end{array}$ & $\begin{array}{c}100 \% \\
\text { Polyester }\end{array}$ & $\begin{array}{c}100 \% \\
\text { Polypropylene }\end{array}$ \\
\hline Structure & $\begin{array}{l}\text { Plain } \\
\text { Weave }\end{array}$ & $\begin{array}{l}\text { 2/2 Basket } \\
\text { Weave }\end{array}$ & $\begin{array}{c}\text { Plain } \\
\text { Weave }\end{array}$ & $\begin{array}{c}\text { Plain } \\
\text { Weave }\end{array}$ & $\begin{array}{c}\text { Plain } \\
\text { Weave }\end{array}$ & $\begin{array}{l}\text { Plain } \\
\text { Weave }\end{array}$ & 2/2 Right Twill \\
\hline Thickness (mm) & 0.37 & 0.55 & 0.58 & 0.33 & 0.23 & 0.43 & 0.63 \\
\hline $\begin{array}{l}\text { Square mass }\left(\mathrm{g} / \mathrm{m}^{2}\right) \\
\text { non-compressed }\end{array}$ & 154 & 225 & 226 & 159 & 102 & 156 & 252 \\
\hline $\begin{array}{l}\text { Density warp/weft } \\
(\text { per } \mathrm{cm})\end{array}$ & $26 / 22$ & $24 / 14$ & $16 / 14$ & $26 / 24$ & $24 / 28$ & $16 / 22$ & $32 / 34$ \\
\hline $\begin{array}{l}\text { Air permeability } \\
\left(\mathrm{I} / \mathrm{m}^{2} / \mathrm{s}\right)\end{array}$ & 277 & 234 & 241 & 272 & 523 & 564 & 74 \\
\hline $\begin{array}{l}\text { Absorption rate } \\
\text { top/bottom }(\% / \mathrm{s})\end{array}$ & $13 / 36$ & $21 / 34$ & $24 / 43$ & $12 / 39$ & $8 / 19$ & $8 / 20$ & $61 / 10$ \\
\hline Porosity (\%) & 70 & 70 & 60 & 70 & 70 & 70 & 70 \\
\hline Drapability (\%) & 34 & 30 & 32 & 39 & 43 & 43 & 10 \\
\hline
\end{tabular}


DIMENSION OF AIR GAP DISTANCE RINGS FOR THE HOTPLATE AND THE LIFTING MECHANISM

Air gap Distance Ring in $100 \%$ foamed polyethylene

\begin{tabular}{|l|c|c|c|}
\hline Thickness & $2 \mathrm{~mm}$ & $4 \mathrm{~mm}$ & $5 \mathrm{~mm}$ \\
\hline $\begin{array}{l}\text { Number of ring on } \\
\text { the hotplate }\end{array}$ & 1 & 2 & 2 \\
\hline $\begin{array}{l}\text { Diameter of outer } \\
\text { circumference }\end{array}$ & $8 \mathrm{~cm}$ & - & - \\
\hline $\begin{array}{l}\text { Diameter of inner } \\
\text { circumference }\end{array}$ & $6 \mathrm{~cm}$ & - & - \\
\hline $\begin{array}{l}\text { Number of ring for the } \\
\text { hotplate lifting mechanism }\end{array}$ & 1 & 1 & 2 \\
\hline $\begin{array}{l}\text { Diameter of outer } \\
\text { circumference }\end{array}$ & $12 \mathrm{~cm}$ & - & - \\
\hline
\end{tabular}

counter thickness; inner rings were placed inside the wind tunnel on the hotplate to create the air gap distance. The outer ring was $12 \mathrm{~cm}$ in diameter on the outer circle and $8 \mathrm{~cm}$ on the inner circle, ring width is $2 \mathrm{~cm}$ for supporting the wider base of the measuring head. The inner ring for the hotplate was $8 \mathrm{~cm}$ in diameter on the outer circle and $6 \mathrm{~cm}$ on the inner circle, ring width is $1 \mathrm{~cm}$. Each sample material was tested five times under $0,4,8,12,16 \mathrm{~mm}$ air gap distance and because of the compact size of the Permetest that allows the possibility to carry out the measurements of thermal and water vapor resistance both in horizontal and vertical positions of the simulated gaps, thus respecting the real conditions of wearing the clothing (figure 1).
Permetest skin model was chosen to use for the experiment for its portable size $(540 \times 230 \times 130 \mathrm{~mm}$, net weight $7 \mathrm{~kg}$ ), versatility to change from a vertical to horizontal orientation in a second and the relatively short measuring time for the test. Permetest skin model is a commercial computer-controlled instrument respecting the modified ISO 11092 Standard. It consists of a box of electronics (with digital indicators and operating knobs), and on the right side of the box attached to an outstanding air tunnel. To the bottom of the tunnel, a measuring head is installed which contains a circular porous hotplate with an $8 \mathrm{~cm}$ diameter measuring area. The measuring head is connected to a lifting mechanism that allows the hotplate to move up and down when putting the sample onto the measuring hotplate. A small square heat power sensor is installed beneath the centre of the hotplate (figure 2).

\section{Experiment}

Air temperature in the climatic chamber was always $23 \pm 0.5^{\circ} \mathrm{C}$ at $40-50 \%$ of relative humidity and the wind speed was set to $1.0 \mathrm{~m} / \mathrm{s}$. Evaporation resistance $R_{e t}$ was measured at these isothermal conditions and the driving force was only the difference between the saturated water vapour pressure in the measuring head of the instrument and the water vapour pressure in the instrument channel. Thermal resistance $R_{c t}$ of the tested fabrics was measured at the same temperature and relative humidity of the air in the channel, but the temperature of the measuring head was increased to $33 \pm 0.1^{\circ} \mathrm{C}$, thus providing the driving force of $10^{\circ} \mathrm{C}$. It is important to mention that

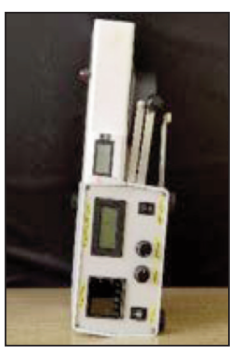

a

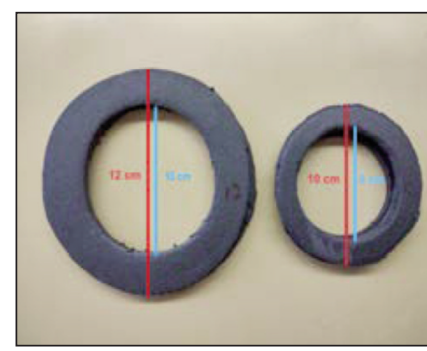

$\boldsymbol{b}$

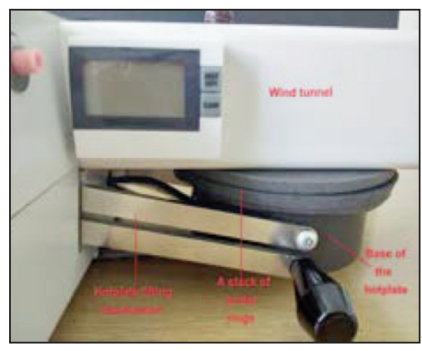

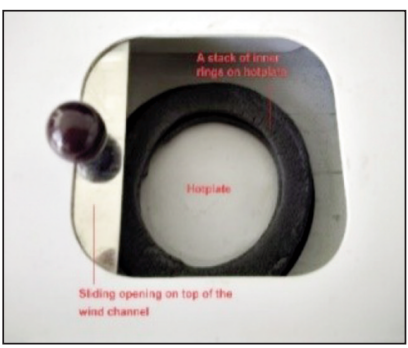

d

Fig. 1. $a$-Permetest skin model in the vertical orientation; $b$-sizes of outer and inner rings; $c$ - placement of outer rings between the wind tunnel and the base of the hotplate; $d$-top view on inner rings placed inside the wind tunnel on the hotplate

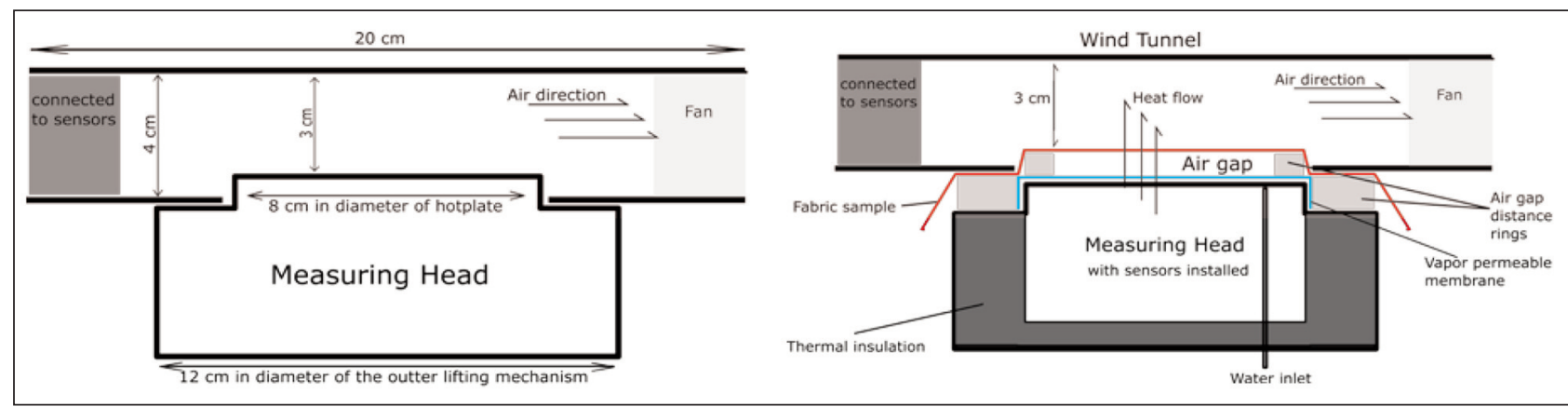

Fig. 2. Cross-section of Permetest showing the dimensions of the instrument and the assemble of the tested sample and the air gap distance rings on the hotplate 
the special program of the instrument compensates all deviations of the air temperature and humidity against the conditions used in the determination of the $R_{e t}$ and $R_{c t}$ parameters of a special hydrophobic calibration fabric in a standard skin model [12]. That is why in several European and African countries the Permetest instrument was accredited as satisfying the ISO 11092 standard.

In real life clothing systems, total thermal resistance $\left(R_{c t}\right)$ unit in $\mathrm{mK} \cdot \mathrm{m}^{2} / \mathrm{W}$ and total evaporative resistance $\left(R_{e t}\right)$ unit in Pa.m²/W, consist of resistances of the boundary layer $\left(R_{c t}\right)_{B L}$ or $\left(R_{e t}\right)_{B L}$, resistances of air gaps $\left(R_{C t}\right)_{A G}$ or $\left(R_{e t}\right)_{A G}$ and resistances of fabrics $\left(R_{c t}\right)_{F}$ or $\left(R_{e t}\right)_{F}$ and are expressed by the equations 1 and 2 .

$$
\begin{aligned}
& \left(R_{c t}\right)_{T o t a l}=(R c t)_{B L}+\left(R_{c t}\right)_{A G}+\left(R_{c t}\right)_{F} \\
& \left(R_{e t}\right)_{T o t a l}=\left(R_{e t}\right)_{B L}+(R e t)_{A G}+(R e t)_{F}
\end{aligned}
$$

The air gaps are important because sometimes air gaps $\left(R_{c t}\right)_{A G}$ or $\left(R_{e t}\right)_{A G}$ may present more than half of the total thermal resistance $\left(R_{c t}\right)$ or evaporative resistance $\left(R_{e t}\right)$ in a clothing system. When using the Permetest skin model, each measurement consists of two tests. The first test without the sample serves for the determination of thermal or evaporative resistance of the boundary layer, the result is hidden and will not be shown on the digital screen. The second test determines the resistance of the tested sample with the air gap, plus the boundary layer. Then from the second value, the instrument program will automatically deduce the value of the boundary layer and gives out the effective value of $R_{c t}$ or $R_{e t}$ which is only including the values of air gap and fabric as expressed in equations 3 and 4 .

$$
\begin{aligned}
& \left(R_{c t}\right)_{\text {Total }}-\left(R_{c t}\right)_{B L}=\left(R_{c t}\right)_{A G}+\left(R_{c t}\right)_{F} \\
& \left(R_{\text {et }}\right)_{\text {Total }}-\left(R_{e t}\right)_{B L}=\left(R_{e t}\right)_{A G}+\left(R_{e t}\right)_{F}
\end{aligned}
$$

When all the measurements of $R_{c t}$ and $R_{e t}$ on air gaps covered by different fabrics are executed; then from the achieved experimental effective values $\left(R_{c t}\right)_{E f f}$ or $\left(R_{e t}\right)_{E f f}$ deduced the $R_{c t}$ or $R_{e t}$ values of these fabrics $\left(R_{c t}\right)_{F}$ or $\left(R_{e t}\right)_{F}$, achieved for the air gap with the zero thickness, to get the $\left(R_{c t}\right)_{A G}$ or $\left(R_{e t}\right)_{A G}$ parameters as in the equations 5 and 6 .

$$
\begin{aligned}
& \left(R_{c t}\right)_{A G}=\left(R_{c t}\right)_{E f f}-\left(R_{c t}\right)_{F} \\
& \left(R_{e t}\right)_{A G}=\left(R_{e t}\right)_{E f f}-\left(R_{e t}\right)_{F}
\end{aligned}
$$

As follows from the common principles of heat and mass transfer, the $R_{c t A G}$ and $R_{\text {etAG }}$ resistances are proportional to the air gap thickness $(h)$ and indirectly to the effective levels of air thermal conductivity $(\lambda)$ in the unit of $\mathrm{W} / \mathrm{mK} \cdot \mathrm{m}$ in equation 7 and diffusion coefficient $\left(D_{p}\right)$ of water vapour in the air in the unit of $\mathrm{kg} / \mathrm{Pa} \cdot \mathrm{s} \cdot \mathrm{m}$ and equation 8 . However, a detailed analysis of these effects would exceed the scope of this study.

$$
\begin{aligned}
& R_{c t A G}=h / \lambda \\
& R_{e t A G}=h / D_{p}
\end{aligned}
$$

\section{RESULTS}

Results are effective data (fabric and air gap only) which are divided into two groups: Thermal resistance group $\left(R_{c t}\right)$ and Evaporative resistance group $\left(R_{e t}\right)$. Each group was analyzed by three statistic methods which were correlation coefficient $(r)$, linear regression $\left(R^{2}\right)$ and two-way ANOVA with replication.

The correlation coefficient of $\mathbf{R}_{\mathrm{ct}}$ and $\mathbf{R}_{\mathrm{et}}$ in vertical and horizontal orientations of seven materials

Results showed in table 3, the correlation coefficient $r$ between the horizontal and vertical orientation of air gaps in $R_{c t} / R_{e t}$ tests of seven materials are very strong and positive: the lowest values $(r=0.94)$ are $80 / 20 \%$ and $70 / 30 \%$ cotton and polyester blend in $R_{c t}$ tests, and other results from $R_{c t} / R_{e t}$ of all materials are close to 1 .

\section{$\mathbf{R}^{2}$ - Regression between the vertically and the horizontally oriented Permetest results from seven materials}

The $R^{2}$ of $R_{c t}$ and $R_{e t}$ from all seven materials in table 4 are demonstrating the strong relationship between the vertical and horizontal air gap orientations that, when any changes in $R_{c t}$, it will be highly reflected by the changes in $R_{e t}$ or vice versa.

\section{Two-way ANOVA with five repetitions results from vertically and horizontally oriented permetest from seven materials}

Results from $R_{c t}$ and $R_{e t}$ of all seven materials show that the $p$-value $<0.01$ which means there is a significant difference between the vertically and the horizontally oriented air gaps from the Permetest skin model. The reason is that even the experiments were done by using the same Permetest skin model, however; the vertical and horizontal orientation of the instrument was causing some difference in the resulting values. $R_{c t}$ experiments were done under nonisothermal conditions, the driving force was the temperature difference. Hot air rises and cool air falls that happen naturally in the vertical air gap, but in the horizontal air gap; the air has to travel through a distance inside the wind channel before exiting. $R_{\text {et }}$ experiments were done under isothermal condition, saturated vapour pressure is the driving force. In the horizontal air gap, water vapour molecules are concentrated at the bottom and rising to the top inside the wind channel. However, when it is in the vertical orientation, the rising water vapour molecules may escape through the fan that will cause the lower values of $R_{e t}$ and it also leads to the $R_{c t} / R_{\text {et }}$ results that the vertically oriented resulting values seem always lower than the horizontally oriented values from the air gap distance 0-16 mm (figures 3, 4 and 5). 
CORRELATION COEFFICIENT RESULTS OF RCT/RET AND THE COMBINATIONS OF VERTICAL/HORIZONTAL ORIENTAL AIR GAP DISTANCES FROM 7 MATERIALS

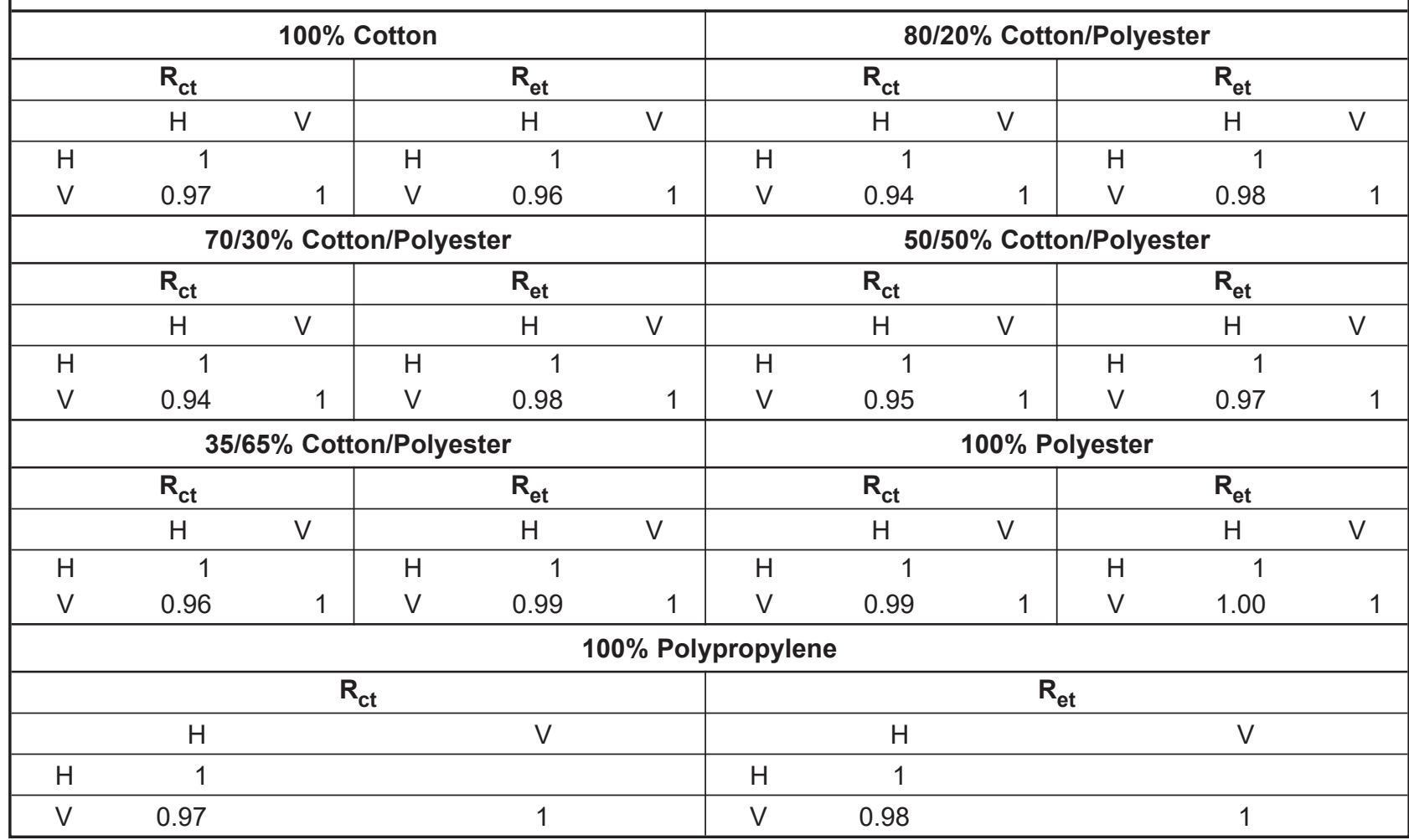

$\mathrm{R}^{2}$ RESULTS OF $\mathrm{R}_{\mathrm{ct}} / \mathrm{R}_{\mathrm{et}}$ BETWEEN VERTICAL AND HORIZONTAL AIR GAPS OF SEVEN MATERIALS

\begin{tabular}{|c|c|c|c|c|c|c|c|}
\hline $\begin{array}{c}\text { Vertical Vs } \\
\text { Horizontal } \\
\mathbf{R}^{\mathbf{2}}\end{array}$ & $\begin{array}{c}\mathbf{1 0 0 \%} \\
\text { Cotton }\end{array}$ & $\begin{array}{c}\mathbf{8 0 / 2 0} \% \\
\text { Cotton/ } \\
\text { Polyester }\end{array}$ & $\begin{array}{c}\mathbf{7 0 / 3 0 \%} \\
\text { Cotton/ } \\
\text { Polyester }\end{array}$ & $\begin{array}{c}\mathbf{5 0 / 5 0 \%} \\
\text { Cotton/ } \\
\text { Polyester }\end{array}$ & $\begin{array}{c}\mathbf{3 5 / 6 5 \%} \\
\text { Cotton/ } \\
\text { Polyester }\end{array}$ & $\begin{array}{c}\mathbf{1 0 0 \%} \\
\text { Polyester }\end{array}$ & $\begin{array}{c}\mathbf{1 0 0 \%} \\
\text { Polypropylene }\end{array}$ \\
\hline $\mathrm{R}_{\mathrm{ct}}$ & 0.94 & 0.89 & 0.88 & 0.89 & 0.92 & 0.98 & 0.95 \\
\hline $\mathrm{R}_{\mathrm{et}}$ & 0.92 & 0.97 & 0.95 & 0.93 & 0.99 & 1 & 0.96 \\
\hline
\end{tabular}

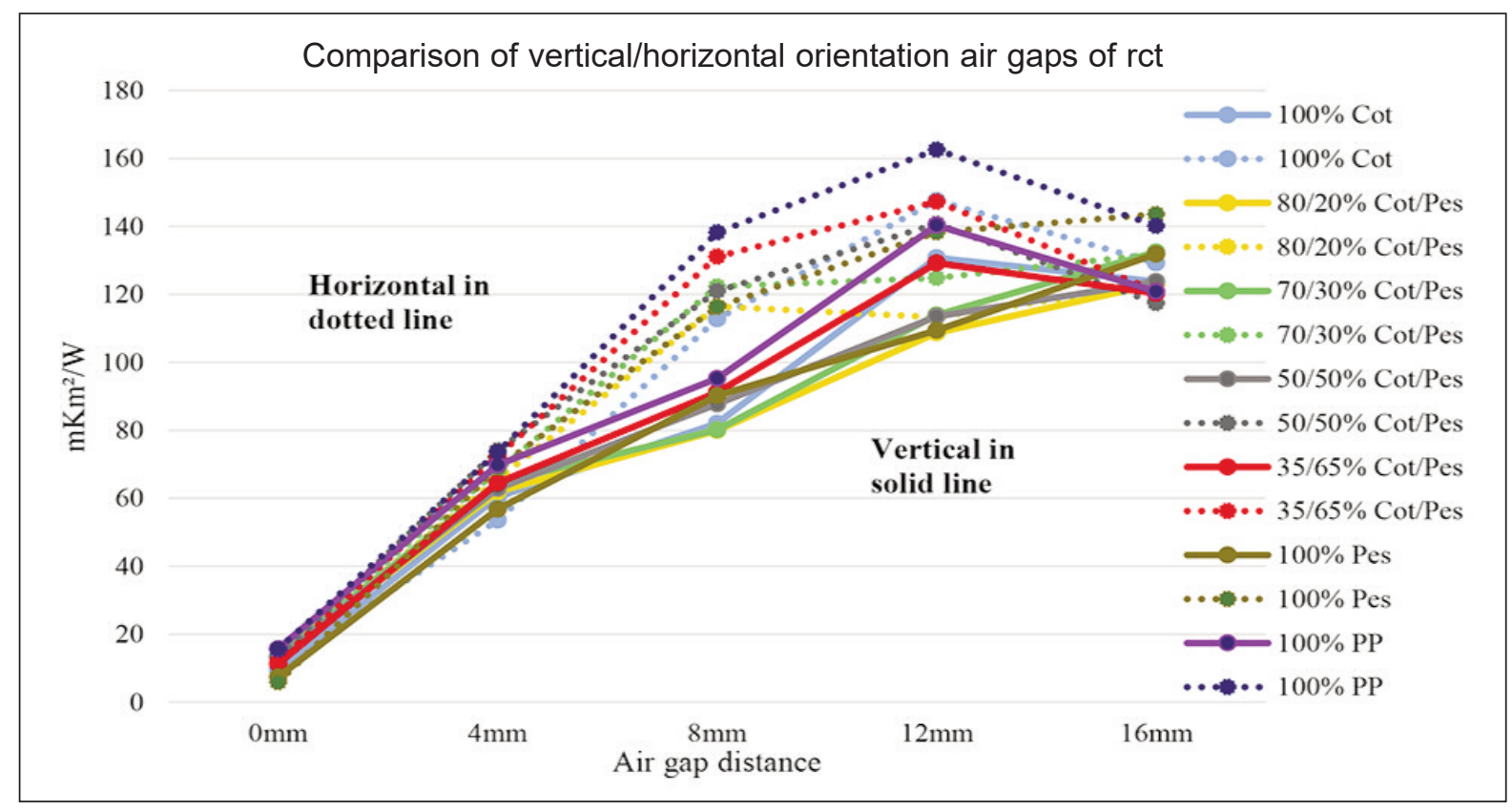

Fig. 3. Visual comparison of vertical and horizontal orientations of the air gap of $R_{c t}$ 


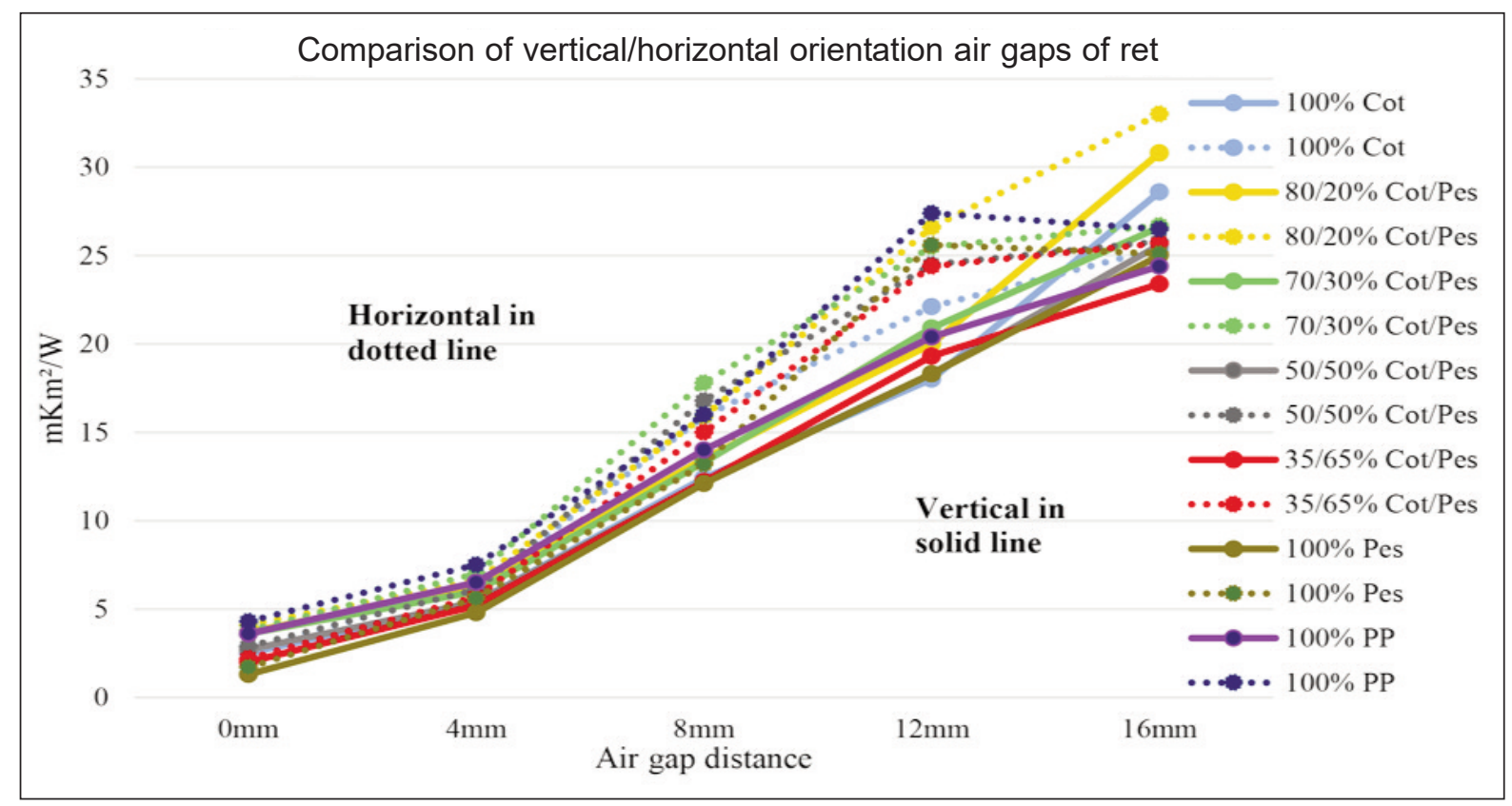

Fig. 4. Visual comparison of vertical and horizontal orientations of the air gap of $R_{\text {et }}$
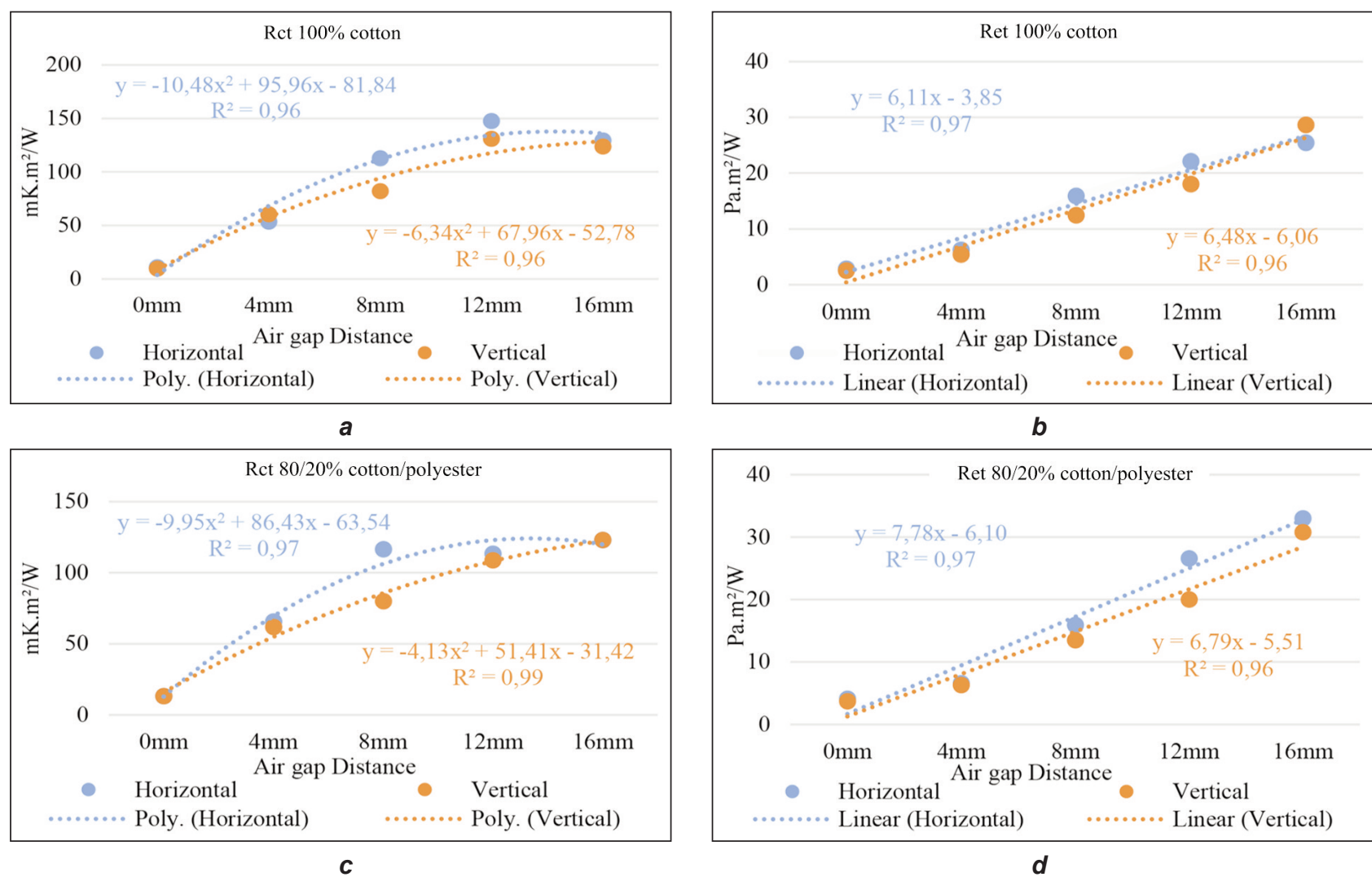

Fig. 5. Samples of the best-fit equation for $R_{c t}$ and $R_{\text {et }}$ for the vertical and horizontal air gap orientation of seven materials: $a-R_{c t} 100 \%$ Cotton; $b-R_{e t} 100 \%$ Cotton; $c-R_{c t} 80 / 20 \%$ Cotton/Polyester; $d-R_{e t} 80 / 20 \%$ Cotton/Polyester

\section{CONCLUSIONS}

Based on the results of thermal resistance $\left(R_{c t}\right)$ and the evaporative resistance $\left(R_{e t}\right)$ of seven materials: $100 \%$ cotton, $100 \%$ polyester and their blends plus $100 \%$ polypropylene; that were tested in vertically and horizontally oriented air gaps of $0,4,8,12$, $16 \mathrm{~mm}$ combinations concluded that (based on the best fitting line, figure 5) increases in the air gap, influences $R_{c t}$ increasing in a polynomial proportional rate and $R_{e t}$ increases in a linear proportional rate. Both rise up to around $12 \mathrm{~mm}$ then the $R_{c t}$ increases slower while $R_{e t}$ is still increasing at a linear rate with the air gap distance increases. Also, from the results of the correlation coefficient showed that all seven materials have a very strong and positive relationship between the horizontally and the vertically oriented 
air gaps from 0 to $16 \mathrm{~mm}$, and each of their values is almost 1 and their $\mathrm{R}^{2}$ also close to 1 which indicates that for every unit increases in the vertical air gap, almost the same amount of unit will increase in the horizontal air gap. More, the two-way ANOVA showed that in the thermal and the evaporative resistance, both $p$-values of all seven materials $p<0.01$ which means that there is a significant difference between the vertical and the horizontal orientations.
This is because when hot and less dense air rises in the vertically oriented air tunnel, it escapes faster than in the horizontal air tunnel where the air has to travel a small distance to the opening of fans, through it to escape. This may also cause the resulting values from the horizontally oriented air gap are a bit higher than the vertically oriented results in general of a single layer of fabric sample tests.

\title{
REFERENCES
}

[1] Fukazawa, T., Lee, G., Matsuoka, T., Kano, K., Tochihara, Y., Heat and Water Vapour Transfer of Protective Clothing Systems in a Cold Environment, Measured with a Newly Developed Sweating Thermal Manikin, In: Eur. J. Appl. Physiol., 2004, 92, 645-648, https://doi.org/10.1007/s00421-004-1124-3

[2] Reiners, P., Kyosev, Y., About the Thermal Conductivity of Multi-layer Clothing, Hochschule Niederrhein, University of Applied Sciences Faculty of Textile and Clothing Technology Mönchengladbach, Germany

[3] Stoffberg, M.A., Hunter, L., Botha, A., The Effect of Fabric Structural Parameters and Fiber Type on the ComfortRelated Properties of Commercial Apparel Fabrics, In: Journal of Natural Fibers, 2015, 12, 6, 505-517, https://doi.org/10.1080/15440478.2014.967370

[4] Bogusławska-Bączek, M., Hes, L., Effective Water Vapour Permeability of Wet Wool Fabric and Blended Fabrics, In: Fibres \& Textiles in Eastern Europe, 2013, 21, 1, 97

[5] Akalović, J., Skenderi, Z, Rogale, S.F., Zdraveva, E., Water Vapor Permeability of Bovine Leather for Making Professional Footwear, In: Leather \& Footwear, 2018, 67, Original Scientific Paper UDC: 675.14.031.1.017.6:685.345

[6] Gericke, A., Pol, J., A Comparative Study of Regenerated Bamboo, Cotton and Viscose Rayon Fabrics, Part 1: Selected Comfort Properties, In: Journal of Family Ecology and Consumer Science, 2010, 38

[7] Satsumoto, Y., Ishikawa, K., Takeuchi, M., Evaluating Quasi-Clothing Heat Transfer: A Comparison of the Vertical Hot Plate and the Thermal Manikin, In: Textile Research Journal, 1997, 67, 7, 503-510, https://doi.org/ 10.1177/004051759706700705

[8] Udayraj, Talukdar, P., Das, A., Alagirusamy, R., Numerical Modeling of Heat Transfer and Fluid Motion in Air Gap between Clothing and Human Body: Effect of Air Gap Orientation and Body Movement, In: International Journal of Heat and Mass Transfer, 2017, 108, 271-291, https://doi.org/10.1016/j.ijheatmasstransfer.2016.12.016

[9] Hes, L., Araujo, M., Simulation of the Effect of Air Gaps between the Skin and a Wet Fabric on Resulting Cooling Flow, In: Textile Res. Journal, 2010, 80, 14, 1488-1497

[10] Joseph, H., Patternmaking for Fashion Design - Armstrong, 2013, ISBN 9781292024813

[11] Cole, J., Patternmaking with Stretch Knit Fabrics, 2016, ISBN 9781501305047

[12] Per Me Test Manual 09 | Measuring Instrument | Calibration, Available at: https://www.scribd.com/document/ 60715185/Per-Me-Test-Manual-09 [Accessed on November 24, 2020]

[13] Richter, J., Staněk, K., Measurements of Water Vapour Permeability - Tightness of Fibreglass Cups and Different Sealants and Comparison of $\mu$-value of Gypsum Plaster Boards, In: Procedia Engineering, 2016, 151, 277-283

\author{
Authors: \\ FREDERICK FUNG ${ }^{1}$, LUBOS HES ${ }^{1}$, ROSHAN UNMAR², VLADIMIR BAJZIK ${ }^{1}$ \\ ${ }^{1}$ Technical University of Liberec, Faculty of Textile Engineering, Evaluation Department, Liberec Czech Republic \\ 2University of Mauritius, Reduit 80837, Mauritius \\ Corresponding author: \\ FREDERICK FUNG \\ e-mail: tassfashion@gmail.com
}

